\title{
Research on Children's Customized Furniture Design Based on Group Technology
}

\author{
Xianqing Xiong ${ }^{1,2}, *$, Guozhen $\mathrm{Lu}^{2}$ and Danting $\mathrm{Lu}^{2}$ \\ 1 Co-Innovation Center of Efficient Processing and Utilization of Forest Resources, Nanjing Forestry University, \\ Nanjing 210037, China \\ 2 College of Furnishings and Industrial Design, Nanjing Forestry University, Nanjing 210037, China; \\ luguozhen@njfu.edu.cn (G.L.); clara6278@126.com (D.L.) \\ * Correspondence: xiongxianqing@njfu.edu.cn
}

check for

updates

Citation: Xiong, X.; Lu, G.; Lu, D. Research on Children's Customized Furniture Design Based on Group Technology. Appl. Sci. 2021, 11, 11371. https://doi.org/10.3390/app112311371

Academic Editor: Maurizio Faccio

Received: 9 September 2021

Accepted: 22 November 2021

Published: 1 December 2021

Publisher's Note: MDPI stays neutral with regard to jurisdictional claims in published maps and institutional affiliations.

Copyright: (c) 2021 by the authors. Licensee MDPI, Basel, Switzerland. This article is an open access article distributed under the terms and conditions of the Creative Commons Attribution (CC BY) license (https:// creativecommons.org/licenses/by/ $4.0 /)$.
Abstract: Recently, solid wood furniture has become the new direction for the development of Chinese furniture industry. In order to realize solid wood customization, the standardization of solid wood parts is a problem for high priority. In this study, a standardized experimental study on children's solid wood furniture parts was carried out by using group technology. Twenty pieces of children's solid wood furniture were selected, including 1084 parts in total with 705 solid wood parts. Then, three key structural features of the parts were analyzed based on the processing similarity principle, including the center line of the long side direction of the parts, the shape of the outside surface of the long side direction and the shape of the outside surface of the short side direction. Moreover, these parts were classified according to the principle of process similarity. Accordingly, a children's solid wood furniture parts family was established, and the distribution of parts in the family was analyzed. In detail, the parts with the dimensional difference within $2 \mathrm{~mm}$ were combined, the dimensional value was mainly based on the value of most parts before the combination and part specifications were optimized on the basis of the original specifications or its $1 / 2$ method. The results show that the category of thickness specification reduced by 20 , and the number of parts included in one thickness specification increased by 2.2 times on average. Moreover, the category of width specification reduced by 12, and the number of parts included in one width specification increased by 1.47 times on average. This not only greatly improves the degree of standardization of solid wood parts but also provides theoretical and practical basis for the digital design of mass customized children's solid wood furniture.

Keywords: group technology; mass customization; furniture design; wood furniture; standardization

\section{Introduction}

China is a major timber consuming country. According to statistics, China's annual timber consumption is about 600 million $\mathrm{m}^{3}$. Although China's timber resources are relatively abundant, timber production only accounts for $15 \%$ of the consumption, making China's timber highly dependent on imports. On this basis, the demand for wood and wood products is growing. In order to improve this situation, the development of China's panels has become more diversified by using different materials and use requirements to manufacture different types of panels. Moreover, the question of how to rationalize the use of panels and to improve the utilization rate of panels has gradually become the focus of wood development [1,2]. Meanwhile, Chinese furniture manufacturing has taken a step from the traditional semi-mechanized and mechanized production mode toward information and digital manufacturing and is gradually advancing toward intelligent manufacturing at a fast pace [3,4]. Group technology (GT) means that all kinds of products and parts of an enterprise are divided into different groups with specific principles based on processing similarity (shape, size and manufacture process) among products, and the products in the same group can be processed by utilizing the same method based 
on the groups (organize production links) so as to improve efficiency and to realize the rationalization of the design, manufacturing and management of products with multispecies and small-batch production [5]. For home furnishing enterprises, group technology is a production technology that uses parts with similar structures, materials and processes to form part families and designs processes specifically for the part families targeted for production, thereby expanding processing batches, reducing part variety and improving labor productivity. Moreover, it is the basis for advanced manufacturing models such as flexible production and mass customization of furniture [6,7].

Nowadays, the children furniture market has gradually become an essential part of the furniture market in China [8]. According to relevant studies on the ergonomics of children, the design has different emphases for different age groups of children $[9,10]$ and should meet both physical and psychological needs [11,12]. There have been many research directions about the design of children furniture since the initial extension of adult furniture such as malleable design, which takes the structure, function and material of the furniture as the innovation point [13] to design a series of functional modules for products with different functions or the same function with various performances and reconstitute new products by selecting and combing modules for modular design [14,15] and multifunctional design [16]. From the perspective of children's emotions, the appearance design of children furniture is more inclined to be interesting and affective [17-19]. According to different scenarios, there are school children furniture, medical children furniture, household children furniture, etc. [20-22]. As children's furniture style is variable in shape and size, it requires a more targeted design compared to adult furniture [23,24]. The parts of children furniture are divided into two types: panel and solid wood. Parents prefer safe and environmentally friendly products when choosing furniture $[25,26]$; hence, solid wood furniture is chosen in most cases $[27,28]$. Compared with panel parts, solid wood parts have various structural sizes; thus, it is necessary to frequently change the tools of the machine and to increase the confirmation of the first piece and process preparation time in production. In view of these facts, solid wood parts are difficult to standardize in production and has caused a lot of waste of manpower, materials and processing time in the production process [29]. However, if group technology is applied to children's furniture production, it will help to standardize children's furniture solid wood parts, reduce production costs and shorten the production cycles, thus realizing the benefits of large-scale production [30].

As an advanced production and management method, group technology classifies the similarities between things into groups by following certain guidelines; hence, the same group of things can be processed through the same method in order to improve productivity [31]. Group technology, which has overcome the defects of multi-variety and small-batch production, plays a significant role in the mass customization industry $[32,33]$. At present, group technology has been successfully applied in many industries $[34,35]$, and the application of this technology in the intelligent manufacturing process of furniture involves all aspects of product manufacturing such as the furniture industry and the research of panel furniture [36,37]. Meanwhile, flexible manufacturing methods are applied to the production of children furniture [38], including product design, fixture, process planning, technological process, interfacing with related software systems and production organization and management, etc. The research studies in furniture manufacturing mainly include the grouping of plate household parts, processes and codes; the grouping of specifications and sizes of American household parts [39]; $32 \mathrm{~mm}$ system and group technology [40]; the grouping of furniture parts based on fuzzy cluster analysis [41]; and the application of group technology in furnish manufacturing informatization [42,43], etc. Suzić et al. [44] investigated mass customization strategies in panel furniture manufacturing, which showed that shop-floor reconfiguration is the key to achieve efficient production, and group technology is advisable to be adopted so as to create product and machine groups in terms of simplifying material flows. The production of chairs was optimized by Tarigan et al. [45], and the results showed that both lean manufacturing and group technology layout can simplify the production process and reduce production time. In related studies, Güven 
and Simsir [46] analyzed that furniture production must accommodate many types of components and applied the group technique to the wood cutting department in a furniture company in Istanbul. The results show that the Fuzzy Clustering method performs better in terms of productivity improvement. Dianita et al. [47] analyzed 43 furniture parts and six processes from Indonesian furniture production. For classifying machines and process in the production layouts, Rank Order Clustering (ROC) and Hollier method were used. The results showed that group technique is important for the improvement of furniture production layout. In addition, various group techniques and algorithms for constructing Clustering Method are worthy of in-depth research. With the development of the wood industry, the question of how to improve timber utilization rate has increasingly become an important goal. In the previous years, the group technology was mainly applied in the adult furniture, and no research had been conducted specifically on the group technology for children's furniture. Meanwhile, children furniture has greater styles and shapes than compared to adult furniture.

To this end, in this study, based on the investigation of children's furniture structure and enterprise production status, children's furniture solid wood parts were selected to carry out parts family classification and size standard optimization on the basis of group technology. The analysis of standardized design research of children's furniture solid wood parts with the group technology is of great guidance to the design and manufacture of children's furniture.

\section{Materials and Methods}

\subsection{Test Step}

This study consists of three steps. First, parts with similar processes are grouped into one category by using PFA method (Production Flow Analysis) to form a machining family. Second, the six categories of parts are optimized in terms of size, and the parts with small differences in thickness (width) use the same size. Finally, a comparison of the parts types before and after optimization is conducted. To help better understand the steps, the flowchart of the article is shown in Figure 1.

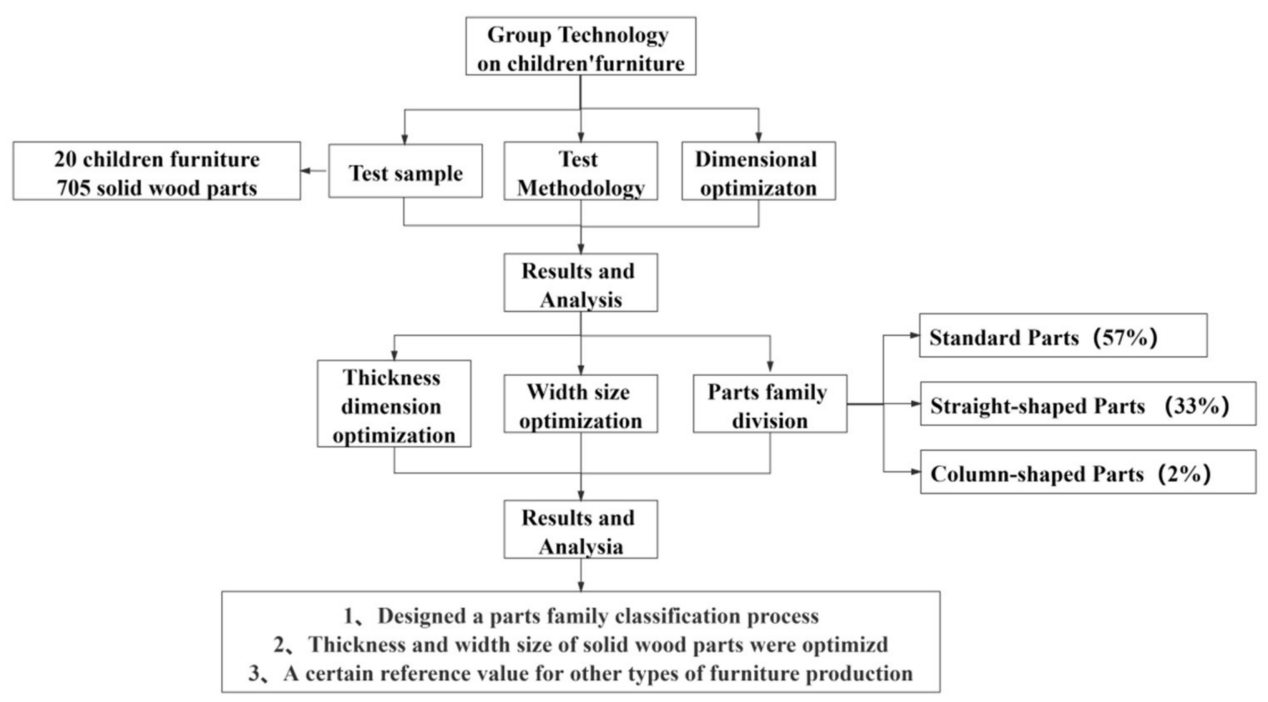

Figure 1. Flowchart.

\subsection{Test Sample}

In this study, a tape measure (scale range: 1 to $5 \mathrm{~mm}$ ) was used to measure 20 children furniture ( 5 children's beds, 5 bedside tables, 5 study tables, and 5 study chairs produced by Meizhou Huisheng Wood Products Co., Ltd., Meizhou, China) as samples, and product modeling is shown in Figure 2. The total number of parts is 1084, of which there are 705 
solid wood parts (299 solid wood parts with different structures) and 379 artificial board parts (including drawer board parts).

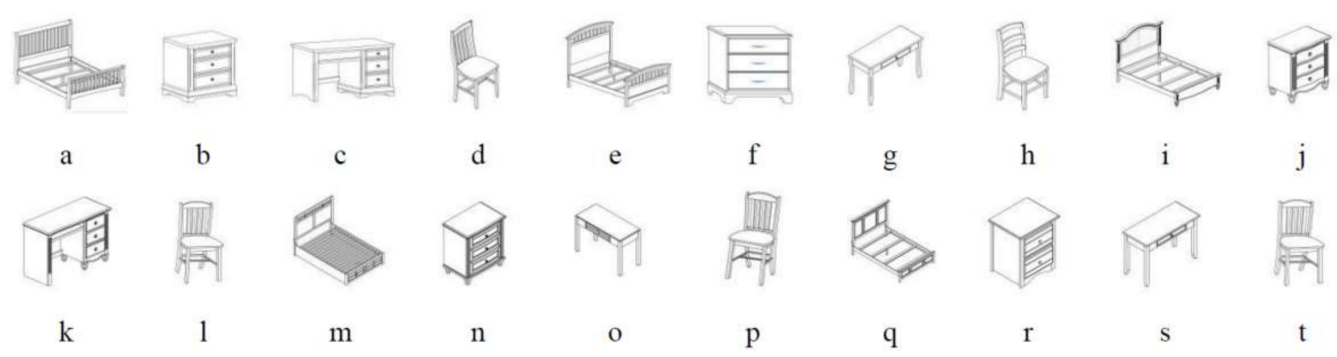

Figure 2. Samples of children's furniture.

\subsection{Test Methodology}

In this study, the principle of group technology is used to divide the size of children's furniture parts into part families through processing and structural similarity and to optimize their size specifications so that the workshop can organize the corresponding production modules according to each part family. The number and layout of the corresponding production equipment are determined according to the distribution of parts in the part families so as to solve the problems of wasteful logistics operation and uneven production tasks caused by the diversity of parts [48]. At the same time, it can reduce frequent tool change, first part confirmation and equipment adjustment time in production. In the subsequent development of new products, according to the classification of parts, standard parts are directly called and specially shaped parts are redesigned or modified, which is not only easy to manage but also can greatly reduce design and development time.

\subsubsection{Parts Family Division}

Solid wood parts are mainly processed by pass type [49] and are machined by sawing, planing, milling and sanding, etc. The processing method is explained in Table 1. Moreover, the feeding direction is generally the long side direction of the parts. Therefore, the axes type of the long side direction of parts determine the shaping processing method, and the shape type of the outside surface of the long side direction determines the tool type of the shaping of the parts (flat for flat knives and curved for type knives). For some parts with more complex structures, additional analysis is required by the type of external surface shape in the short side direction.

Table 1. Processing method.

\begin{tabular}{|c|c|}
\hline Processing Method & Paraphrase \\
\hline Sawing & $\begin{array}{c}\text { A tool that has a long blade with sharp points along one of its edges. } \\
\text { A saw is moved backwards and forwards by hand or driven by } \\
\text { electricity and is used for cutting wood or metal. }\end{array}$ \\
\hline Planing & $\begin{array}{l}\text { A tool used for making wooden surfaces smooth, which has a flat } \\
\text { bottom with a sharp blade in it. }\end{array}$ \\
\hline Milling & $\begin{array}{l}\text { A special equipment used for cutting wood with a round rotating } \\
\text { multi-edge cutter. }\end{array}$ \\
\hline Sanding & A tool to make wood very smooth by sanding it with sandpaper. \\
\hline
\end{tabular}

Based on this, this study focuses on taking three key features of the parts for analysis and dividing the names of the specified part families by different routes, as shown in Figure 3 in the order from 1 to 3. 


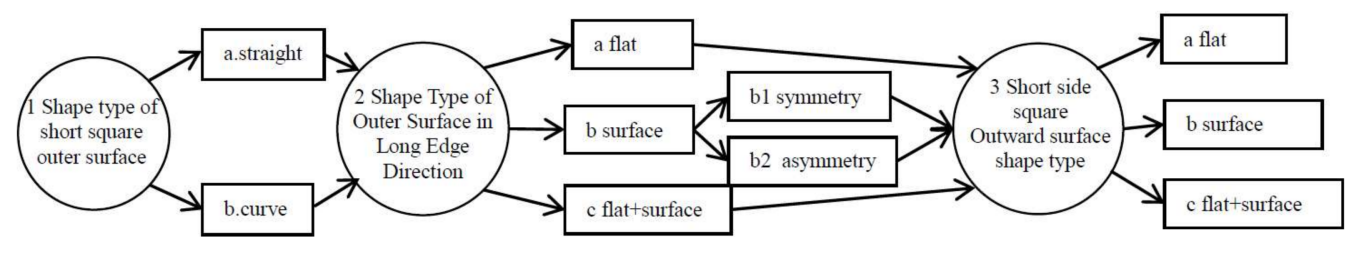

Figure 3. Classification process of parts group.

As shown in Figure 3, Route a-a-a is similar in process; thus, the name of the part family is defined as the block class. Among them, the process flow of triangular wood, connecting wood, mattress bars, edge sealing bars and other parts is similar, and the size and structure forms a certain standard, and each type can be interchangeable and common among different products; thus, the name of this kind of part family is defined as the general part class. With regard to routes $a-a-b, a-a-c, a-b 2-a, a-b 2-b$ and a-b2-c, the name of their part family is specified as a linear modeling class. For route $b-a / b / c-a / b / c$, its part family name is defined as curve modeling class. Moreover, with respect to route $a-b 1-a$, its part family name is specified as a cylindrical class.

Furthermore, for the manmade board parts (including drawer board parts), as their size structures have certain standard specifications and the same process, their part family is specified as a separate class, and this type of part family is named as wood-based panels.

\subsubsection{Dimensional Optimization}

Based on group technology, the shortest side of the parts is specified as the thickness, the shorter side as the width and the longest side as the length. The total number of parts with different thickness (width) specifications and the classification number of thickness (width) specifications are obtained by experiments, and the ratio of thickness (width) specification classification to a total number of parts is calculated. When the ratio is larger, it indicates that the thickness (width) types that are required to process the same number of parts are lower, and the standardization level of parts is higher. Conversely, if the types of timber thickness (width) increase, this means that the standardization of parts is lower, and it is more difficult to both produce the parts and to improve efficiency [50-52]. Therefore, under the circumstance of not affecting the appearance and function of the furniture, the number of thickness (width) dimensions should be appropriately reduced so as to mainly focus on a few more frequently used dimensions, and this dimension should correspond to the raw material dimensions as much as possible, which can reduce processing difficulties and improve production efficiency.

Dimension optimization should follow the following principles:

1. Break the affiliation of parts and merge similar dimensions without affecting the exterior shape and structural process;

2. Use the same width and thickness as much as possible for parts with the same function;

3. Choose the smaller size under the premise of satisfying process and function.

The specific method: The parts with thickness size differences less than $2 \mathrm{~mm}$ are merged into the same thickness. The thickness dimensions after merging are mainly based on the value of a large number of parts before merging and close to the thickness specification of raw materials. Parts with width size differences that are less than $2 \mathrm{~mm}$ are merged into the same width. The width dimensions after merging are mainly based on the value of a large number of parts before merging and close to the width specification of raw materials or its $1 / 2$.

When optimizing, whether the size merges upward or downward should depend on the specific use of the parts, preferentially choosing the side with less impact on the appearance and structure. At the same time, the size of parts with high frequency in the process of investigation is considered. As the structures of the parts and the hole site 
have a unified standard and its length direction size does not change, parts thickness and width sizes do not affect the structure; thus, the positioning of the hole site length direction remains unchanged, and the width or thickness direction is positioned in the middle line of the wide side of the surface.

\section{Results and Discussion}

\subsection{Part Family Division}

Based on these principles and methods, 705 solid wood parts of children's furniture in the samples were divided into part families and counted, and the distribution of parts in each part family is shown in Table 2 . The ratio of the number of parts in the part family to the distribution of material volume is shown in Figure 4.

Table 2. Group division and statistics of children's furniture parts.

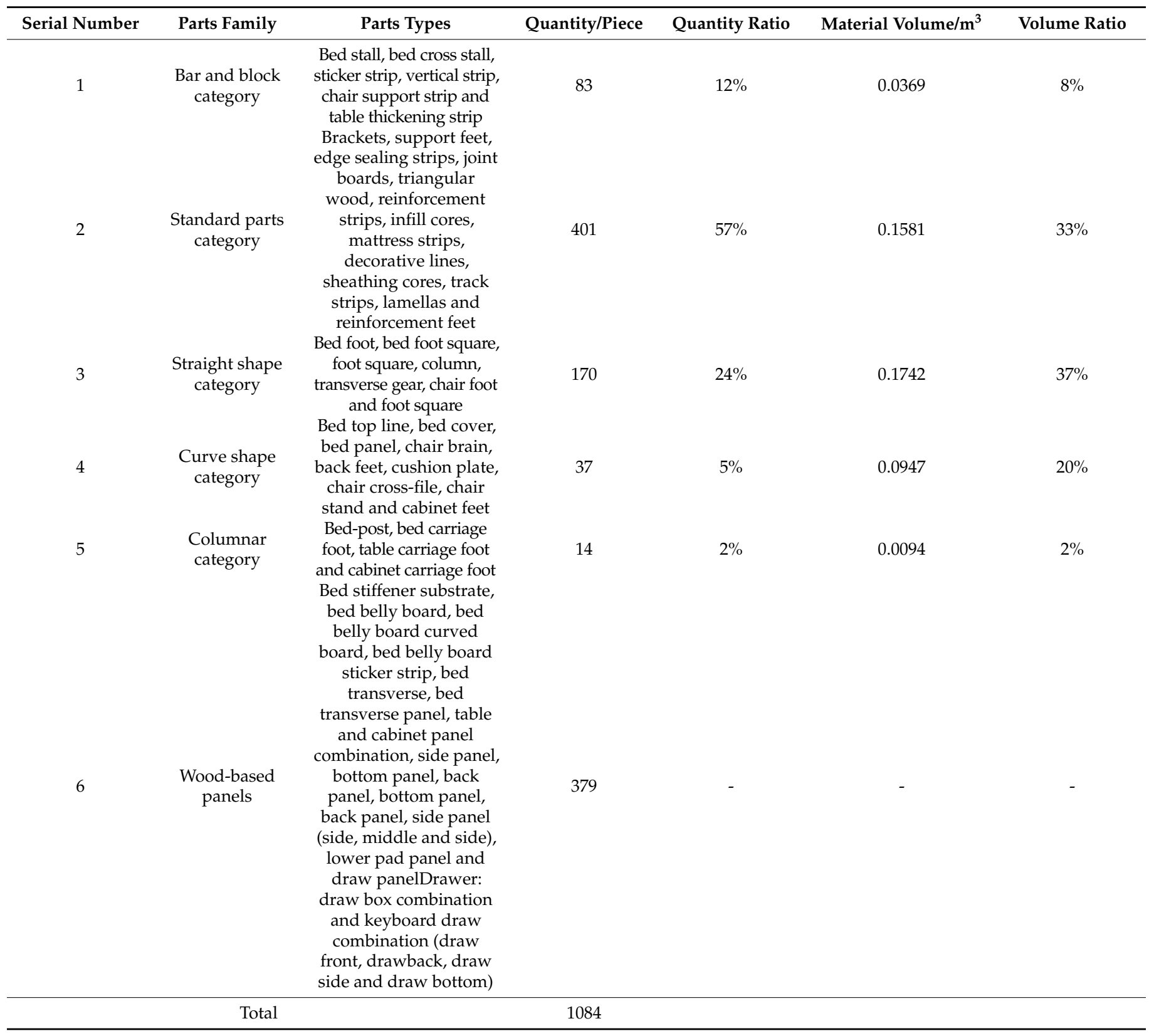



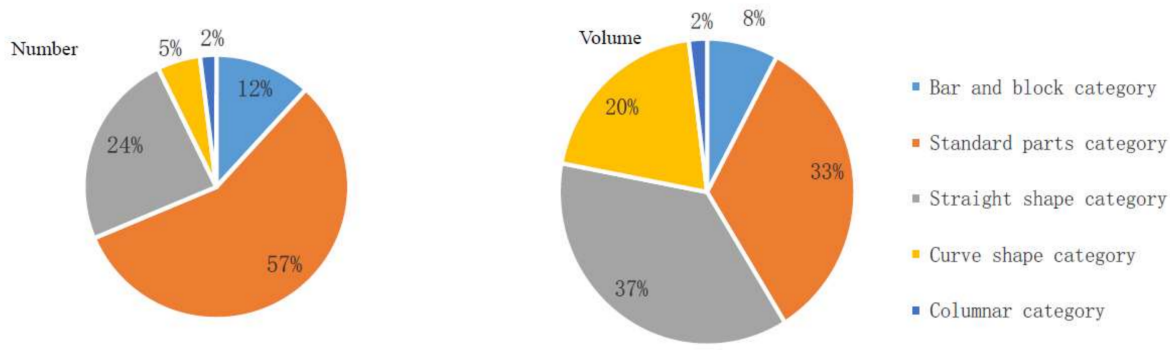

Figure 4. Number and volume proportion of parts in group.

Table 2 and Figure 4 shows the following:

(1) With regard to the number of parts in parts family, standard parts accounted for the largest proportion $(57 \%)$, which is followed by linear molding $(33 \%)$; the two kinds of parts accounted for nearly $90 \%$, and columnar parts accounted for a smaller proportion $(2 \%)$. It can be observed that this kind of part family division is suitable for the pass-through processing method, which can reduce tool change times, first part confirmation and equipment adjustment time during production.

(2) In terms of the volume of parts family, straight shape category parts had a volume of 0.1742 volume $/ \mathrm{m}^{3}$, accounting for $37 \%$, and the standard parts category had a volume of 0.1581 volume $/ \mathrm{m}^{3}$, accounting for $33 \%$, and the two kinds of parts accounted for $70 \%$. It is shown that this not only can improve the utilization rate from the perspective of the process of volume consumables but also can explain the reasonableness of this form of parts family division.

\subsection{Parts Size Optimization}

\subsubsection{Thickness Dimension Optimization}

The 705 parts in the samples were graded in the order of thickness size from small to large, and the number of parts contained in each thickness grade was counted. The results are shown in Table 3, and the distribution of parts in each grade is shown in Figure 5.

Table 3. Statistics of parts thickness and quantity before optimization.

\begin{tabular}{|c|c|c|c|c|c|c|c|c|c|c|c|c|c|c|c|}
\hline $\begin{array}{c}\text { Thickness } \\
\text { grading }\end{array}$ & 1 & 2 & 3 & 4 & 5 & 6 & 7 & 8 & 9 & 10 & 11 & 12 & \multirow{4}{*}{$\begin{array}{l}\text { Total } \\
\text { number } \\
\text { of parts } \\
\text { /piece }\end{array}$} & \multirow{4}{*}{$\begin{array}{l}\text { Thickness } \\
\text { specifica- } \\
\text { tion/species }\end{array}$} & \multirow{4}{*}{$\begin{array}{c}\text { Ratio of total } \\
\text { number of } \\
\text { parts } \\
\text { to thickness } \\
\text { specification }\end{array}$} \\
\hline Size $/ \mathrm{mm}$ & 4.5 & 5 & 8 & 9 & 10 & 12 & 13 & 14 & 15 & 18 & 19 & 20 & & & \\
\hline Quantity/Piece & 6 & 27 & 3 & 8 & 9 & 8 & 24 & 32 & 78 & 41 & 5 & 270 & & & \\
\hline $\begin{array}{l}\text { Thickness } \\
\text { grading }\end{array}$ & 13 & 14 & 15 & 16 & 17 & 18 & 19 & 20 & 21 & 22 & 23 & 24 & & & \\
\hline Size $/ \mathrm{mm}$ & 21 & 22 & 23 & 24 & 25 & 27 & 28 & 30 & 34 & 35 & 36 & 37 & \multirow{5}{*}{705} & \multirow{5}{*}{36} & \multirow{5}{*}{20} \\
\hline Quantity/Piece & 3 & 21 & 8 & 1 & 29 & 7 & 10 & 21 & 7 & 3 & 2 & 1 & & & \\
\hline $\begin{array}{l}\text { Thickness } \\
\text { grading }\end{array}$ & 25 & 26 & 27 & 28 & 29 & 30 & 31 & 32 & 33 & 34 & 35 & 36 & & & \\
\hline Size $/ \mathrm{mm}$ & 38 & 40 & 45 & 50 & 51 & 55 & 58 & 60 & 69 & 80 & 85 & 90 & & & \\
\hline Quantity/Piece & 1 & 38 & 8 & 4 & 4 & 4 & 1 & 2 & 3 & 2 & 10 & 4 & & & \\
\hline
\end{tabular}




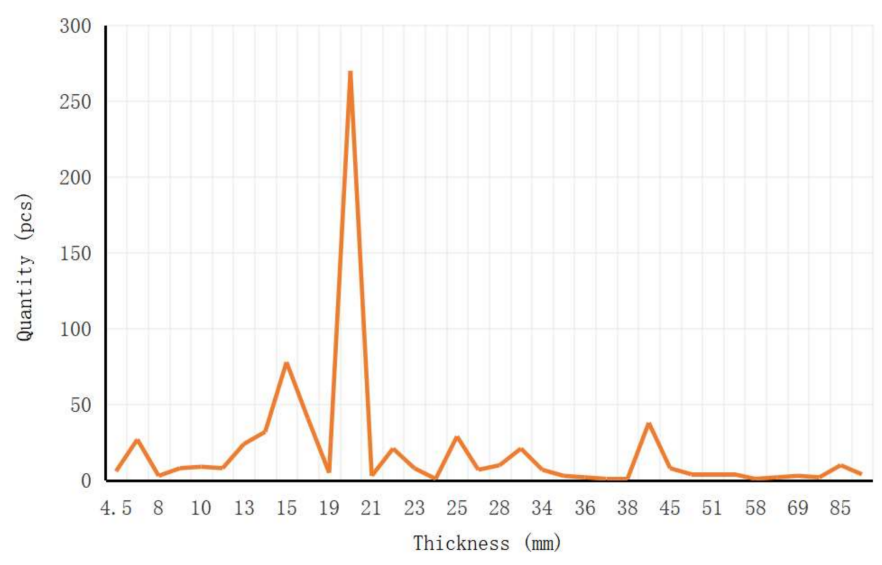

Figure 5. Quantity distribution of parts thickness.

According to the above size optimization method, the thickness of the parts in Table 3 was optimized, and the specific optimization results are shown in Table 4.

Table 4. Statistics of parts thickness and quantity after optimization.

\begin{tabular}{|c|c|c|c|c|c|c|c|c|c|c|c|}
\hline $\begin{array}{l}\text { Thickness } \\
\text { grading }\end{array}$ & $1 \sim 2$ & $3 \sim 5$ & $6 \sim 9$ & $10 \sim 13$ & $14 \sim 17$ & $18 \sim 20$ & $21 \sim 24$ & $25 \sim 26$ & \multirow{4}{*}{$\begin{array}{c}\text { Total } \\
\text { number of } \\
\text { parts/piece }\end{array}$} & \multirow{4}{*}{$\begin{array}{l}\text { Thickness } \\
\text { specifica- } \\
\text { tion/species }\end{array}$} & \multirow{4}{*}{$\begin{array}{l}\text { Ratio of total } \\
\text { number of } \\
\text { parts to } \\
\text { thickness } \\
\text { specification }\end{array}$} \\
\hline Size/mm & 5 & 9 & 14 & 20 & 24 & 29 & 35 & 40 & & & \\
\hline Quantity/Piece & 33 & 20 & 142 & 319 & 59 & 38 & 13 & 39 & & & \\
\hline $\begin{array}{c}\text { Thickness } \\
\text { grading }\end{array}$ & 27 & $28 \sim 29$ & 30 & $31 \sim 32$ & 33 & 34 & 35 & 36 & & & \\
\hline Size $/ \mathrm{mm}$ & 45 & 50 & 55 & 60 & 69 & 80 & 85 & 90 & \multirow{2}{*}{705} & \multirow{2}{*}{16} & \multirow{2}{*}{44} \\
\hline Quantity/Piece & 8 & 8 & 4 & 3 & 3 & 2 & 10 & 4 & & & \\
\hline
\end{tabular}

Figure 6 shows the distribution comparison of thickness specification of the parts before and after optimization.

Before optimization: 36 kinds

After optimization: 16 kinds
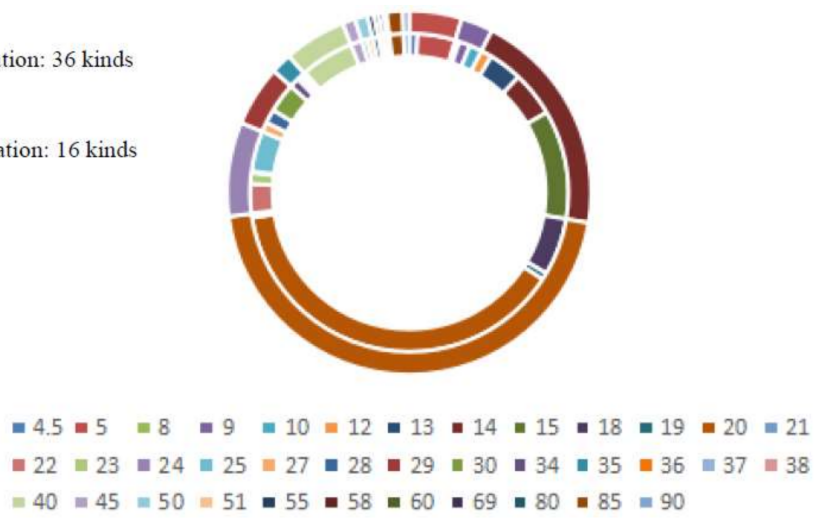

Figure 6. Contrast of thickness specification before and after optimization.

From Figures 5 and 6, it can be observed that there were many thickness specifications of solid wood parts before optimization, and the two thickness sizes of 15 and 20 were more concentrated, and the minimum size of more than zero was increased. After optimization, the total number of parts remained unchanged, the thickness specifications reduced from 36 before optimization to 16, the thickness specification types reduced by 20 and the average number of parts contained in one thickness specification increased from 20 to 44 . The number of parts included in one thickness specification increased from 20 to 44 , which 
was 2.2 times higher than before. Size standardization in the thickness direction of parts greatly improved.

\subsubsection{Width Size Optimization}

The 705 parts in the samples were graded in the order of width size from small to large, and the number of parts contained in each width grade was counted. The results are shown in Table 5, and the distribution of parts in each grade is shown in Figure 7.

Table 5. Statistics of parts width and quantity before optimization.

\begin{tabular}{|c|c|c|c|c|c|c|c|c|c|c|c|c|c|c|c|c|}
\hline $\begin{array}{l}\text { Width } \\
\text { grading }\end{array}$ & 1 & 2 & 3 & 4 & 5 & 6 & 7 & 8 & 9 & 10 & 11 & 12 & 13 & \multirow{4}{*}{$\begin{array}{c}\text { Total } \\
\text { number of } \\
\text { parts/piece }\end{array}$} & \multirow{4}{*}{$\begin{array}{l}\text { Width } \\
\text { specifica- } \\
\text { tion/species }\end{array}$} & \multirow{4}{*}{$\begin{array}{c}\text { Ratio } \\
\text { of total } \\
\text { number of } \\
\text { parts to } \\
\text { width spec- } \\
\text { ification }\end{array}$} \\
\hline Size $/ \mathrm{mm}$ & 9 & 15 & 16 & 19 & 20 & 24 & 25 & 30 & 31 & 35 & 38 & 40 & 42 & & & \\
\hline Quantity/Piece & 6 & 43 & 16 & 30 & 64 & 32 & 51 & 65 & 1 & 55 & 9 & 61 & 4 & & & \\
\hline $\begin{array}{l}\text { Width } \\
\text { grading }\end{array}$ & 14 & 15 & 16 & 17 & 18 & 19 & 20 & 21 & 22 & 23 & 24 & 25 & 26 & & & \\
\hline Size $/ \mathrm{mm}$ & 45 & 47 & 50 & 51 & 52 & 55 & 60 & 64 & 65 & 70 & 76 & 78 & 80 & \multirow{5}{*}{705} & \multirow{5}{*}{37} & \multirow{5}{*}{19} \\
\hline Quantity/Piece & 21 & 2 & 100 & 4 & 1 & 15 & 23 & 10 & 6 & 3 & 3 & 1 & 38 & & & \\
\hline $\begin{array}{l}\text { Width } \\
\text { grading }\end{array}$ & 27 & 28 & 29 & 30 & 31 & 32 & 33 & 34 & 35 & 36 & 37 & & & & & \\
\hline Size $/ \mathrm{mm}$ & 85 & 87 & 90 & 95 & 105 & 110 & 115 & 396 & 462 & 468 & 845 & & & & & \\
\hline Quantity/Piece & 12 & 1 & 7 & 1 & 8 & 6 & 1 & 1 & 2 & 1 & 1 & & & & & \\
\hline
\end{tabular}

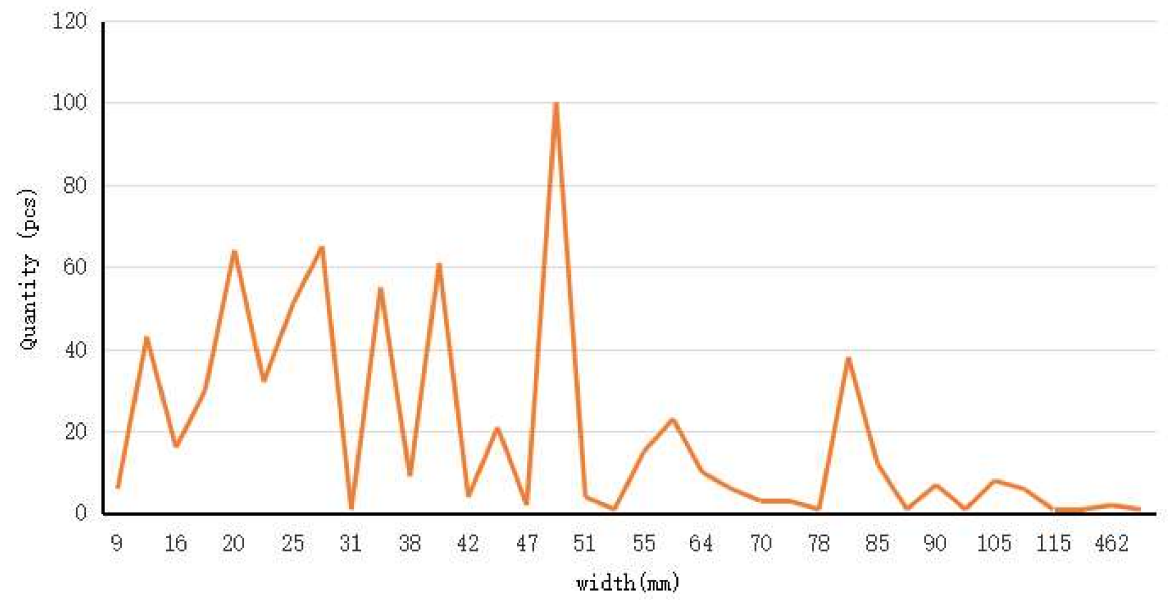

Figure 7. Quantity distribution of parts width.

According to the above size optimization method, the width of the parts in Table 5 was optimized, and the specific optimization results are shown in Table 6.

Table 6. Statistics of parts width and quantity after optimization.

\begin{tabular}{|c|c|c|c|c|c|c|c|c|c|c|c|c|c|c|c|c|}
\hline Width grading & 1 & $2 \sim 3$ & $4 \sim 5$ & $6 \sim 7$ & $8 \sim 9$ & 10 & $11 \sim 13$ & $14 \sim 15$ & $16 \sim 18$ & 19 & 20 & $21 \sim 22$ & 23 & \multirow{4}{*}{$\begin{array}{c}\text { Total } \\
\text { num- } \\
\text { ber of } \\
\text { parts/piece }\end{array}$} & \multirow{4}{*}{$\begin{array}{c}\text { Width } \\
\text { specifica- } \\
\text { tion/species }\end{array}$} & \multirow{4}{*}{$\begin{array}{l}\text { Ratio } \\
\text { of total } \\
\text { number of } \\
\text { parts to } \\
\text { width } \\
\text { specification }\end{array}$} \\
\hline \multirow{2}{*}{$\begin{array}{l}\text { Size/mm } \\
\text { Quantity } \\
\text { /Piece }\end{array}$} & 9 & 15 & 20 & 25 & 30 & 35 & 40 & 45 & 50 & 55 & 60 & 65 & 70 & & & \\
\hline & 6 & 59 & 94 & 83 & 66 & 55 & 74 & 23 & 105 & 15 & 23 & 16 & 3 & & & \\
\hline Width grading & $24 \sim 25$ & 26 & $27 \sim 28$ & 29 & 30 & 31 & 32 & 33 & 34 & 35 & 36 & 37 & & & & \\
\hline $\begin{array}{c}\text { Size } / \mathrm{mm} \\
\text { Quantity/Piece }\end{array}$ & $\begin{array}{c}76 \\
4\end{array}$ & $\begin{array}{l}80 \\
38\end{array}$ & $\begin{array}{l}85 \\
13\end{array}$ & $\begin{array}{c}90 \\
7\end{array}$ & $\begin{array}{c}95 \\
1\end{array}$ & $\begin{array}{c}105 \\
8\end{array}$ & $\begin{array}{c}110 \\
6\end{array}$ & $\begin{array}{c}115 \\
1\end{array}$ & $\begin{array}{c}396 \\
1\end{array}$ & $\begin{array}{c}462 \\
2\end{array}$ & $\begin{array}{c}468 \\
1\end{array}$ & $\begin{array}{c}845 \\
1\end{array}$ & & 705 & 25 & 28 \\
\hline
\end{tabular}

Figure 8 shows the distribution comparison of the number of width specification parts before and after optimization. 


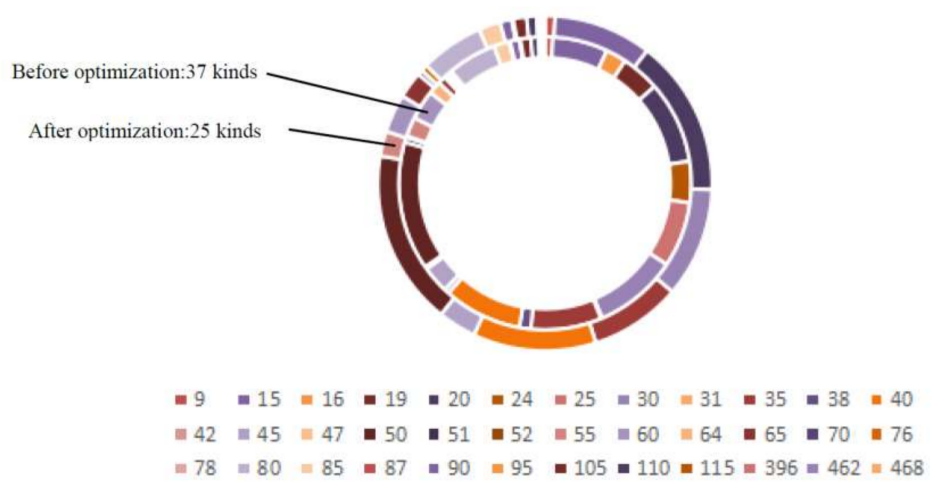

Figure 8. Contrast of width number before and after the optimization.

From Figures 7 and 8, it can be observed that before optimization, the distribution of the number of parts width grade showed multiple peaks, indicating that width dimensions had formed some common size specifications. However, the distance between adjacent peaks was close, and the minimum value greater than zero increased. After optimization, the total number of parts remained unchanged, the width specifications were optimized from the original 37 to 25 , the width specification types reduced by 12 and the average number of parts contained in one width specification increased by 1.47 times from 19 to 28 , indicating that the dimensional standardization in the width direction of parts greatly improved.

Based on a comprehensive analysis of the optimization, it can be observed. that the optimization of the size of children's furniture parts will not significantly affect its overall appearance of the structure but can reduce the diversity of parts size and form a few high-frequency sizes. This means that the number of processes will be increased, the workshop changing of cutting-tool for machines and preparing time will be reduced and processing efficiency will be improved.

\section{Conclusions}

Based on group technology, this paper analyzes the structural characteristics of furniture parts through the principle of processing similarity and optimizes family classification and size standard of children's furniture parts. The following conclusions were reached:

1. By using structure and process similarity analysis, a parts family classification process was designed. Moreover, based on the classification process, different types of parts such as strips, standard parts, straight-shaped parts, curved-shaped parts, columnshaped parts and sheet materials (including draw boxes) were summarized, which provided a basis for workshop layout planning and organizing specialized production. Meanwhile, it reduces the waste related to logistic operations of parts in production.

2. Based on the principle of group technology, 705 pieces of children's furniture parts were selected, and the thickness and width sizes of wood parts were optimized. Twenty types of thickness specifications and twelve types of width specifications were reduced, which improved the degree of standardization of parts and helped to reduce the time for cutting tool of the machine, first piece confirmation and processing preparation in production. Moreover, production efficiency improved.

3. Standardization of furniture parts is the basis for the implementation of flexible production, lean production, information-based production and other advanced manufacturing technologies. The enhancement of the standardization of furniture parts to a certain extent is equivalent to the realization of batch production of diversified furniture. This application has a certain reference value for other types of furniture production. 
Author Contributions: Conceptualization, X.X.; methodology, X.X.; validation, X.X., G.L. and D.L.; investigation, X.X.; data curation, X.X.; writing-original draft preparation, X.X; writing-review and editing, G.L.; visualization, G.L.; supervision, X.X.; funding acquisition, X.X. All authors have read and agreed to the published version of the manuscript.

Funding: This research was funded by the National Key R\&D Program of China (2018YFD0600304), Postgraduate Education Reform Project of Jiangsu Province (SJCX20_0267) and Technology Innovation Alliance of Wood/Bamboo Industry (TIAWBI202010).

Institutional Review Board Statement: Not applicable.

Informed Consent Statement: Not applicable.

Data Availability Statement: Data is contained within the article.

Conflicts of Interest: The authors declare no conflict of interest.

\section{References}

1. Zhao, H. Present Situation of Forest Products Industry and Development Trend of Wood Industry in China. Heilongjiang Sci. Technol. Inf. 2014, 18, 253.

2. Sun, Q.; Qi, Y. Analysis on Wood Demand and Consumption in China. For. Sci. Technol. 2015, 40, 60-62. [CrossRef]

3. Xiong, X.Q.; Yuan, Y.Y.; Fang, L.; Liu, H.; Wu, Z.H. Status and Development Trends of Intelligent Manufacturing in China's Furnishings Industry. For. Prod. J. 2018, 68, 328-336.

4. Xiong, X.; Wu, Z. Present situation and development trend of intelligent manufacturing in home furnishing industry. J. For. Eng. 2018, 3, 11-18.

5. Xu, X.; Cai, J. Group Technology, 2nd ed.; China Machine Press: Beijing, China, 1997; pp. 1-9, ISBN 7-111-05621-3.

6. Hung, K.T.; Maleki, H. Applying group technology to the forging industry. Prod. Plan. Control 2014, 25, 134-148. [CrossRef]

7. Li, Y.; Ying-huan, C. Application of Modular Design Methods in Children Furniture Design. Packag. Eng. 2010, $031,25-28$.

8. Dai, X. Discussion on Design Conception Market of Chinese Children Furniture. China For. Prod. 2002, $29,3$.

9. Salvador, C.; Vicente, J.; Martins, J.P. Ergonomics in children's furniture-emotional attachment. In Proceedings of the 5th International Conference AHFE, Kraków, Poland, 19-23 July 2014; pp. 5478-5485.

10. Du, M.; Shen, L.; Tan, L.; Wang, Y. Research and Analysis of Children's Dining Chairs Based on Ergonomics. Furnit. Inter. Des. 2021, 1, 16-19. [CrossRef]

11. Xiao, Y. Research on Children Furniture Design Based on Children's Psychological and Physiological Characteristics. Master's Thesis, Central South University of Forestry and Technology, Changsha, China, 2011.

12. Zeng, G.; Lin, X. Study on the Development and Design of Grown-up Furniture for Children Based on Interest. Furnit. Inter. Des. 2014, 12, 24-25.

13. Yang, X.; Wen, J. Based on Malleable Children Furniture Design. Design 2018, 13, 68-69. [CrossRef]

14. Ling, Y. Design of Modular Furniture. Ph.D. Thesis, Northeast Forestry University, Harbin, China, 2007.

15. Yuan, L. Thw Design Reaearch of Children Furniture Modular. Master's Thesis, Taiyuan University of Technology, Taiyuan, China, 2013.

16. Zhang, N.; Guan, H.; Zurlo, F. Research and Innovation of Children Furniture Design. J. Nanjing Arts Inst. Fine Arts Des. 2018, 34, 190-192.

17. Liu, S. Research on Emotional Design of Children Furniture. Master's Thesis, Southwest Jiaotong University, Chengdu, China, 2009.

18. Zhao, H.; Sun, D.; Kong, J.; Li, S. Research on Emotional Design of School-age Children's Furniture. China For. Prod. 2020, 57, $56-60$.

19. Zhang, L.; Tang, L.; Ren, Y. Research on Interesting Furniture Design of Children's Ward. Furnit. Inter. Des. 2017, 7, $26-27$.

20. Knight, G.; Noyes, J. Children's behaviour and the design of school furniture. Ergonomics 1999, 42, 747-760. [CrossRef] [PubMed]

21. Yanto; Lu, C.W.; Lu, J.M. Evaluation of the Indonesian National Standard for elementary school furniture based on children's anthropometry. Appl. Ergon. 2017, 62, 168-181.

22. Ekaterinushkina, A.V.; Zhdanova, N.S.; Mishukovskaya, J.I. Study of Functional Features of Furniture and Equipment in the Design of Recreation of Children's Polyclinics. IOP Conf. Ser. Mater. Sci. Eng. 2018, 463, 032028. [CrossRef]

23. Bai, H.; Xiong, X.; Duan, Y. Analysis on The Application of Children's Growth Needs in Children's Chair Design. Furniture 2011, 42,5 .

24. Guo, H.; Miao, Y.; Xiong, X. Research on Chinese Symbol Implanted Design for Children Toys. Furnit. Inter. Des. $2018,3,16-19$.

25. Chen, Y.; Peng, X. The Analysis on Children Furniture Industry in China. China For. Prod. Ind. 2015, 42, 10-12.

26. Wan, M.; Toppinen, A. Effects of perceived product quality and Lifestyles of Health and Sustainability (LOHAS) on consumer price preferences for children's furniture in China. J. For. Econ. 2016, 22, 52-67. [CrossRef]

27. Jonsson, O.; Lindberg, S.; Roos, A.; Hugosson, M.; Lindström, M. Consumer perceptions and preferences on solid wood, wood-based panels, and composites: A repertory grid study. Wood Fiber Sci. 2008, 40, 663-678.

28. Zhang, X.; Wang, X.; Meng, L. Safety Design of Children Furniture. J. Liaoning Inst. Technol. 2008, 10, 78-79.

29. Sun, Y. Classification and coding of parts based on group technology. Precise Manuf. Autom. 2014, 1, 24. [CrossRef] 
30. Xiong, X.Q.; Guo, W.J.; Fang, L.; Zhang, M.; Wu, Z.H.; Lu, R.; Miyakoshi, T. Current state and development trend of Chinese furniture industry. J. Wood Science. Off. J. Jpn. Wood Res. Soc. 2017, 63, 433-444. [CrossRef]

31. Sun, Z.; Yin, G. Research on the application of GT (Group Technology) in the modern manufacture. Mech. Res. Appl. 2006, 19, 4-5.

32. Wan, M.; Chen, J.; Toppinen, A. Consumers' Environmental Perceptions of Children's Furniture in China. For. Prod. J. 2015, 65, 395-405. [CrossRef]

33. Yuan, P. Research on Quality Control Based on Group Technology-Application of SPC in Multivarieties and Small Batch Manufacturing. Master's Thesis, Nanjing University of Aeronautics and Astronautics, Nanjing, China, 2003.

34. Wang, J.B.; Wang, J.J. Single machine group scheduling with time dependent processing times and ready times. Inf. Sci. 2014, 275, 226-231. [CrossRef]

35. Tang, N.; Cai, J.; Li, Y.; Zhang, K. Method of classify identification of group technology base on the diffuse prior distribution. Syst. Eng. Electronics. Syst. Eng. Electron. 2012, 34, 197-202.

36. Wu, X.; Qiu, X. From GT to Mass-Customization. China Mech. Eng. 2001, 12, 319-321.

37. Li, G. Application of Group Technology in Furniture Production. Furnit. Inter. Des. 1997, 5, 12-13. [CrossRef]

38. Fu, Y.; Hai, L. Research on the Feasibility of the Utilization of Group Technology in Panel Type Furniture. Furnit. Inter. Des. 2007, 1, 76-77. [CrossRef]

39. Li, J. Simplifying Part Size of American Style Furniture to Adopt Group Technology. China For. Prod. Ind. 2004, 2, 40-43. [CrossRef]

40. Li, X. The Variant Design of Furniture Based Modules with $32 \mathrm{~mm}$ System through Group Technology Optimization. Packag. Eng. 2015, 4, 55-59. [CrossRef]

41. Ye, J.; Jun, L.; Yan, D. Customized cabinet part classifification manufacturing technology based on fuzzy clustering algorithm. J. For. Eng. 2016, 1, 133-138.

42. Duray, R.; Ward, P.T.; Milligan, G.W.; Berry, W.L. Approaches to mass customization: Configurations and empirical validation. J. Oper. Manag. 2000, 18, 605-625. [CrossRef]

43. Legleiter, C.J.; Goodchild, M.F. Alternative representations of in-stream habitat: Classification using remote sensing, hydraulic modeling, and fuzzy logic. Int. J. Geogr. Inf. Sci. 2005, 19, 29-50. [CrossRef]

44. Suzić, N.; Stevanov, B.; Ćosić, I.; Anišić, Z.; Sremčev, N. Customizing products through the application of group technology: A case study of furniture manufacturing. Stroj. Vestn. J. Mech. Eng. 2012, 58, 724-731. [CrossRef]

45. Tarigan, U.; Tarigan, U.P.P.; Sukirman, V. Integration of Lean Manufacturing and Group Technology Layout to increase productionspeed in the Manufacture of Furniture. IOP Conf. Ser. Mater. Sci. Eng. 2019, 528, 012058. [CrossRef]

46. Gven, L.; Fuat, M.R. Machine-Part Formation for Cellular Manufacturing in Group Technology: An Application for Furniture Company. Sak. Univ. J. Sci. 2021, 25, 466-483. [CrossRef]

47. Dianita, O.; Djorgie, T.; Herliansyah, M.K. Improvement of Production Layout in the Furniture Industry in Indonesia with the Concept of Group Technology. Adv. Comput. Methods Knowl. Eng. 2020, 1121, 304-310. [CrossRef]

48. Han, J.; Wu, Z. Construction and application of manufacturing execution system for panel customized furniture enterprises. J. For. Eng. 2018, 3, 149-155.

49. Zhu, J.; Wu, Z.; Huang, Q. Constructing technology of enterprise information platform for furniture manufacturing enterprises. J. For. Eng. 2019, 4, 151-157.

50. Xiong, X.; Ma, Q.; Yuan, Y.; Wu, Z.; Zhang, M. Current situation and key manufacturing considerations of green furniture in China: A review. J. Clean. Prod. 2020, 267, 121957. [CrossRef]

51. Liu, Y.; Wu, Z.; Xu, W. Review of the Application of Life Cycle Assessment to Furniture Industry. World For. Res. 2019, 32, 56-60.

52. Yuan, Y.; Liu, W.; Li, G. Research on users' cognition of different preferences based on ERPs. J. For. Eng. 2019, 004, 152-158. 